\title{
Uptake and conversion of carbonyl sulfide in a lawn soil
}

\author{
Junfeng Liu ${ }^{\mathrm{a}, \mathrm{b}}$, Yujing $\mathrm{Mu}^{\mathrm{b}, *}$, Chunmei Geng ${ }^{\mathrm{b}}$, Yunbo $\mathrm{Yu}^{\mathrm{b}}$, \\ Hong $\mathrm{He}^{\mathrm{b}}$, Yuanhang Zhang ${ }^{\mathrm{a}}$ \\ ${ }^{a}$ Department of Environmental Sciences, Peking University, Beijing 100871, China \\ ${ }^{\mathrm{b}}$ Research Center for Eco-Environmental Sciences, Chinese Academy of Sciences, Beijing 100085, China \\ Received 14 September 2006; received in revised form 25 February 2007; accepted 28 February 2007
}

\begin{abstract}
Carbonyl sulfide (COS) exchange fluxes between a lawn soil and the atmosphere as well as influencing factors (temperature and water content of soil) were investigated using a static cuvette. The optimal soil temperature and water content for COS consumption were about $298 \mathrm{~K}$ and $12.5 \%$, respectively. The converting products of the consumed COS in the lawn soil were researched using in situ diffuse reflectance infrared Fourier transform spectroscopy (DRIFTS). The peaks of gas-phase products of $\mathrm{CO}_{2}$ and surface $\mathrm{HCO}_{3}^{-}, \mathrm{HS}^{-}, \mathrm{SO}_{3}^{2-}, \mathrm{HSO}_{3}^{-}$, and $\mathrm{SO}_{4}^{2-}$ species were observed. The possible mechanism of COS conversion in the lawn soil was discussed. The conversion rates of consumed COS into water-soluble sulfate in the lawn soil were studied by ion chromatography (IC). The experimental results show that about $50 \%$ sulfur from the soil consumed COS was eventually converted into water-soluble sulfate.
\end{abstract}

(C) 2007 Elsevier Ltd. All rights reserved.

Keywords: COS; Sulfate; $\mathrm{H}_{2} \mathrm{~S}$

\section{Introduction}

Carbonyl sulfide (COS) is the most abundant atmospheric sulfur gas in the remote troposphere (Möller, 1984; Andreae and Crutzen, 1997). COS is relatively inert in the troposphere and its tropospheric lifetime is greater than 1 year (Khalil and Rasmussen, 1984; Andreae and Crutzen, 1997). It can be transported into the stratosphere where its photo-oxidation is considered to be an important source for stratospheric sulfate aerosol layer during volcanically quiescent periods (Crutzen, 1976; Turco et al., 1980; Andreae and Crutzen, 1997).

\footnotetext{
*Corresponding author. Tel.: + 861062849125 ; fax: +861062923563 .

E-mail address: yjmu@rcees.ac.cn (Y. Mu).
}

Stratospheric aerosols influence the earth's radiation budget (Crutzen, 1976; Turco et al., 1980; Andreae and Crutzen, 1997), and are also believed to enhance ozone depletion (Crutzen, 1976). Understanding the global COS cycle is therefore of considerable importance.

Soils were previously considered to represent one of the dominant sources of COS (Adams et al., 1981; Khalil and Rasmussen, 1984; Möller, 1984). However, recent field studies present convincing evidence that soils act more as a sink than as a source for COS (Castro and Galloway, 1991; Kesselmeier et al., 1999; Kuhn et al., 1999; Watts, 2000). As the ambient concentration of a given trace gas controls the direction as well as the magnitude of its flux between biosphere and the atmosphere, earlier studies using COS free air for purging the 
enclosures masked the uptake capability of soils (Castro and Galloway, 1991). Although there is still only few data, and the estimation contains considerable uncertainty, it is now believed that oxic soils are acknowledged globally as a sink for atmospheric COS instead of as a source (Castro and Galloway, 1991; Kesselmeier et al., 1999; Kuhn et al., 1999; Watts, 2000).

Previous studies have indicated that carbonic anhydrase (CA) is the key enzyme for uptake of COS by different biological organisms (Bartell et al., 1993; Protoschill-Krebs et al., 1996; Kesselmeier et al., 1999; Kuhn and Kesselmeier, 2000; Kesselmeier and Hubert, 2002). Protoschill-Krebs et al. pointed out that CA in vivo splits COS into $\mathrm{CO}_{2}$ and $\mathrm{H}_{2} \mathrm{~S}$ (Protoschill-Krebs et al., 1996). However, the emission of $\mathrm{H}_{2} \mathrm{~S}$ only accounted for $1-2 \%$ of the sulfur deposited as COS to the soil/ plant system investigated by Bartell et al. (1993). Bartell et al. pointed out that further physiological study is required to resolve this problem (Bartell et al., 1993).

To our knowledge, very few studies focus on the conversion of COS in soils (Ren, 1999). In this study, high concentration (about $14 \mathrm{ppm}$ ) of COS was used to investigate its exchange rates and the possible conversion paths of COS in the lawn soil.

\section{Materials and methods}

\subsection{Soil sampling}

Lawn soil samples, consisting of sandy loam, were collected from a lawn in the north of Beijing city $(115.26 \mathrm{E}, 39.58 \mathrm{~N})$. Samples were taken from the top $5 \mathrm{~cm}$. Samples of $5 \mathrm{~kg}$ soil were collected at five different locations and mixed uniformly. The mixed sample was sieved with a stainless steel sieve (20 mesh size) for removal of twigs, pieces of roots, etc. The soil samples were stored in a polyethylene bag at $\sim 276 \mathrm{~K}$ until being used. Soil water content was varied by air-drying or by moistening with deionized water. Dry weight of soil sample was obtained by drying it at $378 \mathrm{~K}$ for $12 \mathrm{~h}$ in an oven. The characteristics were determined according to standard protocols (Liu, 1996). Inorganic elementary analysis of the soil samples was carried out on an Elementary Vario El (Germany) system. X-ray fluorescence (XRF) data were obtained from a Bruker S4 Explorer spectrometer.

\subsection{Enclosure system}

COS uptake by the lawn soil was investigated using a static glass vessel with total volume of $2.72 \mathrm{~L}$. The glass vessel consists of two glass tubes and a sampling port. The two glass tubes were connected with a pump (MB-21E, Metal Bellows Corp.) to insure the gases in the vessel well mixed. The sampling port was made of Teflon, which was sealed with a silicon septum. The vessel was put into a thermostatic bath to keep temperature constant. Prior to experiment, $2 \mathrm{~mL}$ of standard COS $\left(2 \%, \operatorname{COS} / \mathrm{N}_{2}\right.$, Scott Specialty Gases Inc.) was injected into the vessel and incubated for $24 \mathrm{~h}$. The change of COS concentrations was within the precision of our system $(<6 \%)$, indicating that the leakage and adsorption of COS in the system could be negligible. Soil samples of $50 \mathrm{~g}$ were placed into the vessel, and synthetic air passed for $5 \mathrm{~min}$ through the vessel, then sealed immediately. After the soil was preincubated for $30 \mathrm{~min}$, a certain volume of standard COS was injected into the vessel, followed by $100 \mathrm{~mL}$ air to maintain the system in a positive pressure state.

\subsection{Gas analyses}

The headspace gas in the static glass vessel was analyzed on a gas chromatograph (GC-6A, Shimadzu) equipped with flame photometric detector. The detailed description of the analyzing method has been reported elsewhere (Mu et al., 2002). The relative precision of the measurements was $6 \%$, on the basis of 10 replicates ( $\mathrm{Mu}$ et al., 2002).

\subsection{COS exchange rate measurement}

The concentration of COS in the vessel containing the investigated soil showed a linear correlation $\left(R^{2}>0.95\right)$ with time (less than $\left.50 \mathrm{~min}\right)$ under our experimental conditions. The exchange rate $\left(F_{\mathrm{COS}}\right.$, nmol $\mathrm{g}^{-1} \mathrm{~h}^{-1}$ ) of COS between soil and the atmosphere can be calculated on the basis of the slope $\kappa\left(\mathrm{nmol} \mathrm{L}{ }^{-1} \mathrm{~min}^{-1}\right)$ of the line, the volume of the glass vessel $(V, \mathrm{~L})$ and the dry weight of the soil samples $(W, \mathrm{~g})$ :

$F_{\mathrm{COS}}=\kappa \times V \times 60 / \mathrm{W}$

\subsection{Determination of water-soluble sulfate}

After being exposed to COS for a given time, the investigated soil was washed with $250 \mathrm{~mL}$ deionized water and transported into a $500 \mathrm{~mL}$ cone flask. Then 
the cone flask was sealed immediately and shaken for 5 min on a swag bed (Liu, 1996). After stilling of the mixture for 2-3 min, the supernatant extracted liquid was swilled into a canister. The mixture was centrifuged for $30 \mathrm{~min}$ at $3000 \mathrm{rmin}^{-1}$. The supernatant extracted liquid was filtered through a $0.45 \mu \mathrm{m}$ filter. The concentration of sulfate in the solution was analyzed by ion chromatography (IC).

The IC was equipped with a guard column (IonPac AG14A-SC, $4 \mathrm{~mm}$, Dionex, CA) to eliminate the organic matter, an analytical column (AS14A-SC, $4 \mathrm{~mm}$, Dionex, CA), an anion suppressor ASRS-ULTRA (4 mm, Dionex, CA) and a pulsed electrochemical detector (Dionex, CA). The eluant consisted of $3.5 \mathrm{mmol} \mathrm{L}^{-1} \mathrm{Na}_{2} \mathrm{CO}_{3} / 1 \mathrm{mmol} \mathrm{L}^{-1} \mathrm{NaHCO}_{3}$ and was passed through the system at a flow rate of $1.2 \mathrm{~mL} \mathrm{~min}^{-1}$. The injection volume of the liquid sample was $25 \mu \mathrm{L}$. The concentration of $\mathrm{SO}_{4}^{2-}$ was calculated on the basis of its peak area. Calibration curve was derived for $\mathrm{SO}_{4}^{2-}$ with concentrations ranged from 10.4 to $208.3 \mu \mathrm{mol} \mathrm{L}^{-1}$.

\subsection{In situ DRIFTS experiments}

In situ diffuse reflectance infrared Fourier transform spectroscopy (DRIFTS) spectra were recorded on a Nexus 670 FT-IR spectrometer (Thermo Nicolet Instrument Corporation), equipped with an in situ diffuse reflection chamber and a high-sensitivity mercury cadmium telluride (MCT) detector cooled by liquid nitrogen. The lawn soil samples for the in situ DRIFTS studies (about $30 \mathrm{mg}$ ) were placed into a ceramic crucible in the in situ chamber. Mass flow controllers and a temperature controller were used to control the reaction conditions. Prior to recording the DRIFTS spectrum, the lawn soil samples were placed in situ in synthetic air at $298 \mathrm{~K}$ for $30 \mathrm{~min}$, and a reference spectrum was measured. To prevent water loss from the soil, water vapor was supplied with the gas stream of $\mathrm{O}_{2}$ and carried into in situ DRIFTS chamber. The infrared spectra were collected and analyzed using a data acquisition computer installed with the OMNIC 6.0 software (Nicolet Corp.). All spectra reported here were recorded at a resolution of $4 \mathrm{~cm}^{-1}$ for 100 scans.

\section{Results and discussion}

\subsection{Soil characteristics}

The lawn soil characteristics were determined according to standard protocols (Liu, 1996). Some properties of the lawn soil samples are as follows: $\mathrm{pH} 7.84, W_{\text {water }} 10.8 \%, C_{\text {organic }} 9.63 \mathrm{~g} \mathrm{~kg}^{-1}, \mathrm{OM}$ $16.6 \mathrm{~g} \mathrm{~kg}^{-1}, \quad N_{\text {total }} 0.75 \mathrm{~g} \mathrm{~kg}^{-1}, \quad P_{\text {total }} 0.93 \mathrm{~g} \mathrm{~kg}^{-1}$, $S_{\text {total }} 0.20 \mathrm{~g} \mathrm{~kg}^{-1}, \mathrm{SO}_{4}^{2-} 29.2 \mathrm{mg} \mathrm{kg}^{-1}$. The inorganic elemental composition of the soil samples was determined by XRF measurement. The major inorganic element percentages in the lawn soil samples are as follows: $\mathrm{Si} 25.39 \%, \mathrm{Fe} 10.73 \%$, Ca $9.93 \%, \mathrm{~K} 4.98 \%, \mathrm{Al} 4.94 \%$.

\subsection{Uptake of COS in the lawn soil under varying temperatures and water content}

COS uptake by the lawn soil (water content was $10.5 \%$ ) was investigated under varying temperature from 278 to $313 \mathrm{~K}$. Fig. 1A shows the COS uptake rates in relation to the temperature regimes. The uptake rate of COS by the lawn soil increased with temperature up to an optimal at $298 \mathrm{~K}$, followed by a decrease at higher temperature. A similar pattern of COS uptake was also observed by previous studies (Lehmann and Conrad, 1996; Kesselmeier et al., 1999). The optimal temperature for COS uptake in soil was in the range between 283 and $318 \mathrm{~K}$ reported by Lehmann and Conrad (1996), and in the range between 288 and $293 \mathrm{~K}$ reported by Kesselmeier et al. (1999).

The exchange rates of COS under 10 different water contents of the lawn soil (0-30\% dry weight) were also investigated. Fig. 1B shows the correlation between the water contents and the COS uptake rates of the lawn soil. The ambient temperature was held constant near the temperature optimal (298 K, see Fig. 1A). The uptake rate of COS increases sharply as the water content increases, and reaches a maximum around $12.5 \%$, then followed by decrease at higher water content. The optimal water content for COS uptake is in the range from $7.5 \%$ to $15 \%$, which agreed very well with the optimal range reported by Kesselmeier et al. (1999). Their results indicated a zero exchange at water content below $6 \%$. However, the COS uptake rate was evident when water content was below $5 \%$ in this study. The high COS concentration used in present work may magnify its uptake rate.

It should be mentioned that the uptake rates measured by this study must be overestimated due to extremely high concentration of COS being used (Conrad and Meuser, 2000). However, the nonlinear relationship between COS uptake rate and temperature or water content was similar to previous study which used ambient air (COS 
A

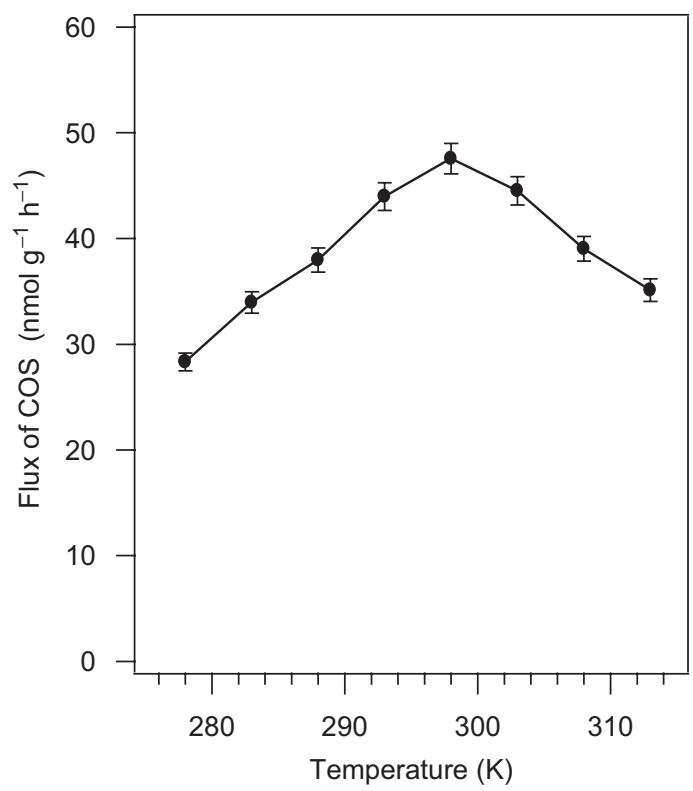

B

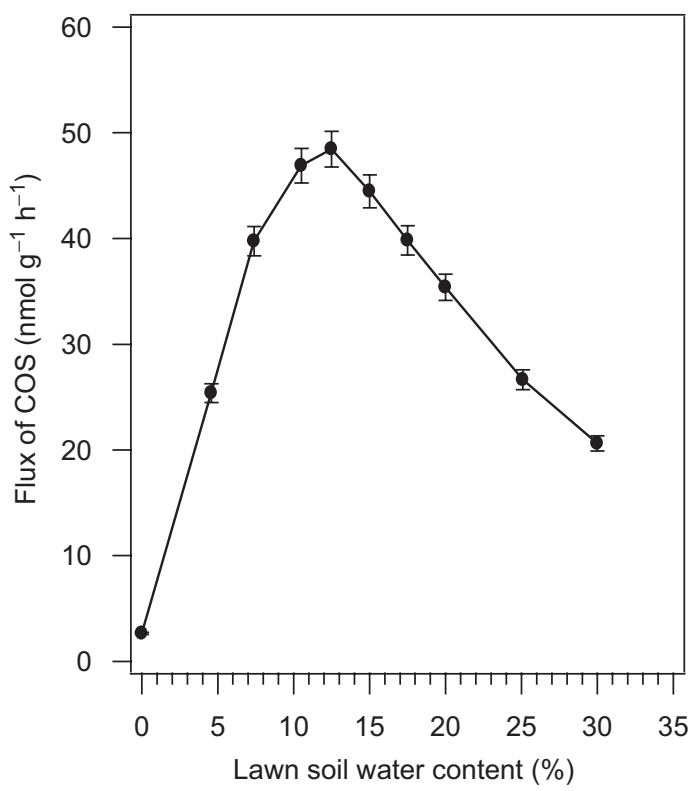

Fig. 1. COS uptake in the lawn soil (the water content of soil was $10.5 \%$ ) varies with the temperature regimes (A). COS uptake in the lawn soil (the temperature of soil was $298 \mathrm{~K}$ ) in relation to the soil water content (B). The initial COS concentration in all experiments was $14 \mathrm{ppm}$. All the data replicated two or three times and used the average value.

concentration of $\sim 500 \mathrm{pptv}$ ) as sweep gas (Lehmann and Conrad, 1996; Kesselmeier et al., 1999), indicating that the biological process was probably the dominant path for COS uptake by the lawn soil under fumigation of high COS concentration. To further examine whether the COS uptake depended on physiology, the lawn soil was heated in an oven at $433 \mathrm{~K}$ for $2 \mathrm{~h}$, then the sterilized lawn soil was moistened or not with deionized water to the optimal soil water content $(12.5 \%)$. Fig. 2 shows COS exchange rates between the lawn soil and the atmosphere. The original lawn soil absorbed COS very rapidly, whereas the sterilized lawn soil absorbed COS very moderately. Therefore, biological processes might be mainly responsible for COS uptake by the lawn soil under high COS concentration.

Kesselmeier et al. (1999) pointed out that carbonic anhydrase (CA) can be regarded as the dominant factor for consumption of COS by their investigated soil. The observed optimal soil water content and temperature pointed to an enzymatically catalyzed process (Radmer and Kok, 1979; Kesselmeier et al., 1999; Kuhn and Kesselmeier, 2000). An enzyme increases the turnover with increasing temperature, but this trend is superimposed by a decrease of activity if the temperature

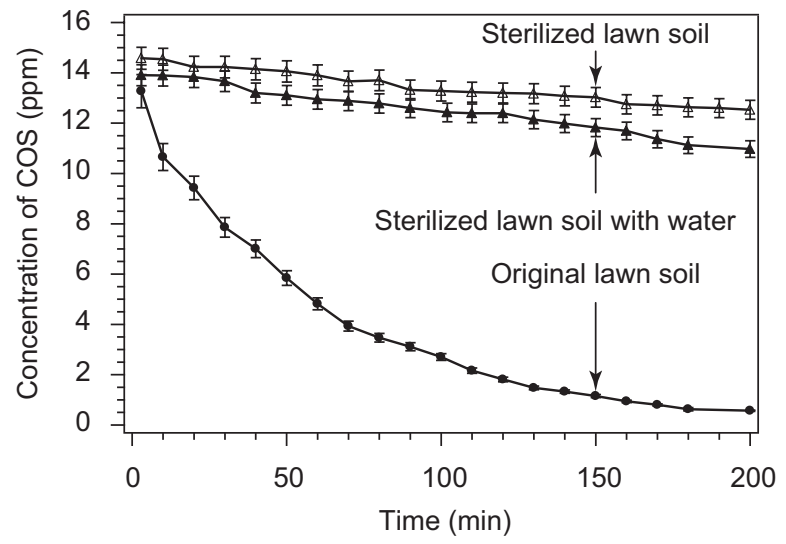

Fig. 2. Concentration of COS versus time in the original lawn soil, the sterilized lawn soil moistening with water, and the sterilized lawn soil at $298 \mathrm{~K}$.

range exceeds a certain value owing to reorganization and/or denaturation of the enzyme structures (Kesselmeier et al., 1999). In addition, COS uptake is strongly dependent on oxygen. The uptake rate of COS by the lawn soil samples decreased $70 \%$ when the air in the vessel was changed into high purity nitrogen. This implied that the biological organisms for the uptake of COS are the aerobe. 


\subsection{The conversion of COS in the lawn soil}

In order to research the possible products from COS conversion in the lawn soil in detail, the in situ DRIFTS experiments were performed. Fig. 3A shows the changes in the in situ DRIFTS spectra on the lawn soil surface. After the lawn soil was exposed to a flow of $500 \mathrm{ppm}$ COS in synthetic air at $298 \mathrm{~K}$ for $10 \mathrm{~min}$, the in situ DRIFTS spectrum was recorded and shown as line a in Fig. 3A. Following that, the inlet and outlet were closed for $60 \mathrm{~min}$, and then the in situ DRIFTS spectrum was recorded and shown as line b. As line a in Fig. 3A shows, after the lawn soil was exposed to COS for $10 \mathrm{~min}$ at $298 \mathrm{~K}$, many bands appeared. Strong peaks due to gasphase COS appeared at 2071 and $2052 \mathrm{~cm}^{-1}$ (Lavalley et al., 1979). The peaks at 2361 and $2337 \mathrm{~cm}^{-1}$ are attributed to gaseous carbon dioxide $\left(\mathrm{CO}_{2}\right)$ (Amenomiya et al., 1977; Morterra et al., 1977; Rege and Yang, 2001). The peak located at $1560 \mathrm{~cm}^{-1}$ is assigned to surface hydrogen thiocarbonate $\left(\mathrm{HSCO}_{2}^{-}\right)$species as an intermediate of the hydrolysis of COS (Lavalley et al., 1979; Hoggan et al., 1994). At the same time, the bands at 1653 and $1437 \mathrm{~cm}^{-1}$ due to surface $\mathrm{HCO}_{3}^{-}$species are also appeared (Amenomiya et al., 1977; Morterra et al., 1977; Lavalley et al., 1979; Rege and Yang, 2001). The subtract spectrum from $b$ to a (amplified 10 times) also shows that, after the lawn soil exposed to $\mathrm{COS}$ in the closed system for $60 \mathrm{~min}$, the peaks for gas-phase $\mathrm{CO}_{2}$, surface $\mathrm{HCO}_{3}^{-}$, and $\mathrm{HSCO}_{2}^{-}$species increase in intensity with time, while the peaks for gaseous COS gradually decrease. These results indicated that the exposure of the lawn soil to $\mathrm{COS}$ could result in the formation of gas-phase $\mathrm{CO}_{2}$, surface $\mathrm{HCO}_{3}^{-}$, and $\mathrm{HSCO}_{2}^{-}$species, etc. at $298 \mathrm{~K}$.

Because the quantity of COS added in the closed system was very small, the peaks of products were very faint. To further confirm the products from conversion of COS on the surface of the lawn soil, a similar experiment was also performed in a flow system for the original lawn soil (Fig. 3B). The surface $\mathrm{HSO}_{3}^{-}\left(1242 \mathrm{~cm}^{-1}\right.$, Laniecki et al., 1987; Mitchell et al., 1996) and $\mathrm{SO}_{4}^{2-}$ species $\left(1363 \mathrm{~cm}^{-1}\right.$, Saur et al., 1986; Meunier and Ross, 2000; Goodman et al., 2001) were observed in addition to the surface $\mathrm{HCO}_{3}^{-}$and $\mathrm{HSCO}_{2}^{-}$species. It is also found

B

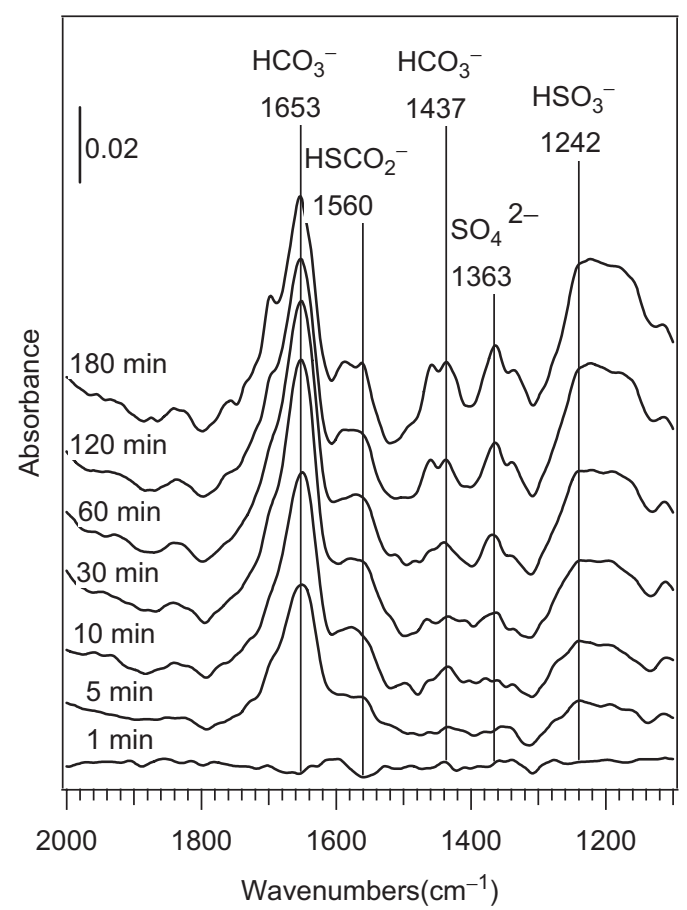

Fig. 3. (A) The in situ DRIFTS spectra of the lawn soil after exposure to $500 \mathrm{ppm}$ COS in synthetic air for $10 \mathrm{~min}$ (a), then in the closed system for $60 \mathrm{~min}$ (b), and the subtracted spectrum from b to a (amplified 10 times). (B) Dynamic changes of in situ DRIFTS spectra of the lawn soil as a function of time at $298 \mathrm{~K}$ in a flow of $500 \mathrm{ppm}$ COS in synthetic air. The water content of the lawn soil was $10.5 \%$ and the temperature was $298 \mathrm{~K}$. 
that the peaks for surface $\mathrm{HCO}_{3}^{-}, \mathrm{HSO}_{3}^{-}, \mathrm{HSCO}^{-}$, and $\mathrm{SO}_{4}^{2-}$ species increase in intensity with time in the soil.

As mentioned above, CA enzyme in vivo splits COS into $\mathrm{CO}_{2}$ and $\mathrm{H}_{2} \mathrm{~S}$ (Protoschill-Krebs et al., 1996). However, Bartell et al. (1993) observed the emission of $\mathrm{H}_{2} \mathrm{~S}$ only account for $1-2 \%$ of the sulfur deposited as COS to the soil/plant system and no $\mathrm{H}_{2} \mathrm{~S}$ were detected in our above experiments, which were probably due to its high reactive activity on the surface of the soil. To further investigate the formation of $\mathrm{H}_{2} \mathrm{~S}$ from the conversion of $\mathrm{COS}$ in the lawn soil, in situ DRIFTS experiment with higher concentration COS was performed. The lawn soil were exposed to a flow of $5000 \mathrm{ppm}$ COS in synthetic air at $298 \mathrm{~K}$ for $10 \mathrm{~min}$ (line a in Fig. 4), and then the inlet and outlet were closed for $6 \mathrm{~h}$ (line $\mathrm{b}$ in Fig. 4). It is evident that a new peak at $2517 \mathrm{~cm}^{-1}$ due to the surface $\mathrm{HS}^{-}$species, which derived from the reaction of $\mathrm{H}_{2} \mathrm{~S}$ with surface hydroxyl (Lavalley et al., 1979; Davydov et al., 1998; Travert et al., 2002), was observed. In addition, the bands at 1057 and $1040 \mathrm{~cm}^{-1}$ are due to surface $\mathrm{SO}_{3}^{2-}$ species (Chang, 1978; Laperdrix et al., 2000; Goodman et al., 2001). The negative peak observed at $1653 \mathrm{~cm}^{-1}$ and a broad peak ranging from 3000 to $3500 \mathrm{~cm}^{-1}$, were assigned to adsorbed water (Meunier and Ross, 2000; Goodman et al., 2001; Rege and Yang, 2001). As the subtract spectrum shown, after the lawn soil exposed to $\mathrm{COS}$ in the closed system for $6 \mathrm{~h}$, the peaks for gas-phase $\mathrm{CO}_{2}$, surface $\mathrm{HCO}_{3}^{-}$, and $\mathrm{SO}_{4}^{2-}$ species increase in intensity with time, while the peaks for gaseous $\mathrm{COS}$, adsorbed water and surface $\mathrm{SO}_{3}^{2-}$ species gradually decrease. The observed $\mathrm{CO}_{2}$ increase and waterconsumption in the vessel containing the lawn soil may partly be due to COS hydrolysis, soil respiration and COS consumption through the $\mathrm{CA}$ enzyme. It should be noted that surface $\mathrm{SO}_{3}^{2-}$ could be gradually converted to $\mathrm{SO}_{4}^{2-}$ species on the surface of the lawn soil (Fig. 4C).

The above results indicated that the exposure of the lawn soil to COS could result in the formation of gas-phase $\mathrm{CO}_{2}$, surface $\mathrm{HCO}_{3}^{-}, \mathrm{HS}^{-}, \mathrm{SO}_{3}^{2-}$, and $\mathrm{SO}_{4}^{2-}$ species in air at $298 \mathrm{~K}$. The surface $\mathrm{SO}_{3}^{2-}$ species was an intermediate, and surface $\mathrm{SO}_{4}^{2-}$ species was a final production for the COS conversion in the lawn soil.

The in situ DRIFTS experiments confirmed the formation of surface $\mathrm{SO}_{4}^{2-}$ species. However, the signal of surface $\mathrm{SO}_{4}^{2-}$ species is too weak to quantify it. In order to investigate the conversion
A

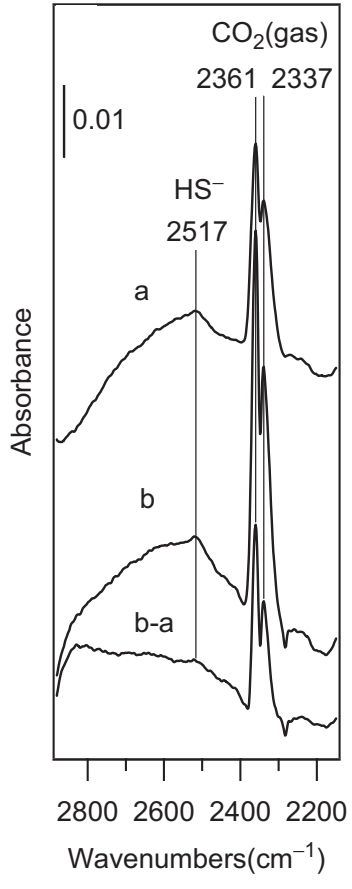

B

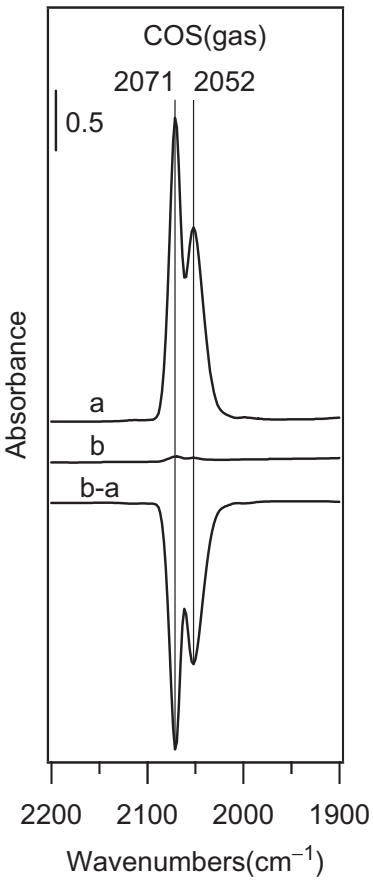

C

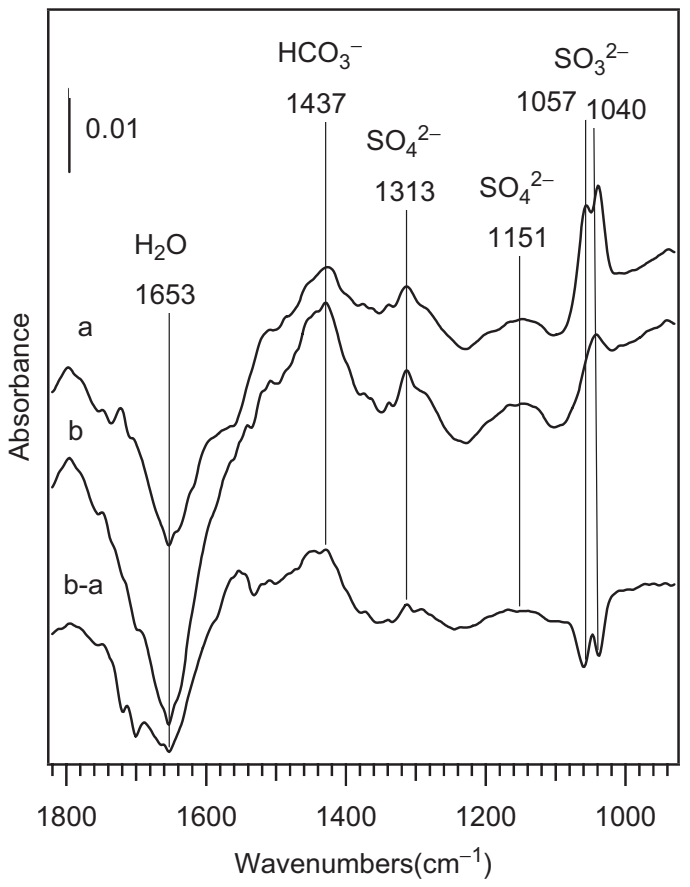

Fig. 4. Dynamic changes of in situ DRIFTS spectra of the lawn soil as a function of time after exposure to $5000 \mathrm{ppm}$ COS in synthetic air for (a) $10 \mathrm{~min}$, then in the closed system for (b) $6 \mathrm{~h}$. The soil water content was $10.5 \%$ and the temperature was $298 \mathrm{~K}$. 
rate of soluble sulfate, the IC was used to quantify sulfate. COS $(1.072 \mathrm{mg})$ was injected into the vessel containing the investigated original lawn soil (the water content of the lawn soil was $10.5 \%$ ) incubated at $298 \mathrm{~K}$. Fig. 5A shows the rates of COS conversion to water-soluble sulfate versus time. The rates of COS conversion into water-soluble sulfate increased rapidly with COS exposure time up to $24 \mathrm{~h}$, and then remained constant. No COS could be detected after $6 \mathrm{~h}$ incubation, only $22 \%$ of COS was converted into the water-soluble sulfate, whereas about $50 \%$ COS was converted into water-soluble sulfate after $24 \mathrm{~h}$ incubation, indicating a time lag existing between COS uptake and its conversion. This phenomenon was supported by the evidence that the conversion of the sulfite to sulfate provided by the in situ DRIFTS experiments (Fig. 4C).

We also performed a series of experiments under different COS additions (0.1-8.04 $\mathrm{mg}$ ) at $298 \mathrm{~K}$ for $48 \mathrm{~h}$. As shown in Fig. 5B, for all experiments, the conversion rates of COS to water-soluble sulfate, seemed to be independent of the amount of COS addition, and were about $50 \%$. Considering the soil has a strong adsorption effect on sulfate, the rates of COS conversion to sulfate must higher than that of the observed water-soluble sulfate.

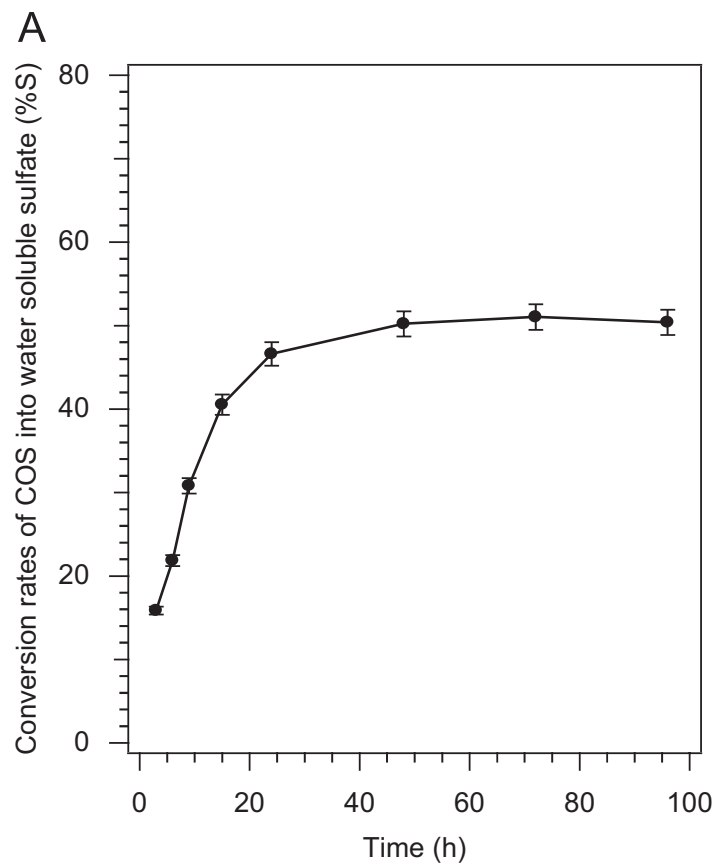

3.4. The pathway of uptake and conversion of COS in the lawn soil

Kim and Katayama (2000) also observed sulfate formation in thiocyanate-containing waste water treatment using sulfur-oxidizing bacteria-Thiobacillus thioparus THI115. COS was found to be the intermediate during the degradation of thiocyanate, and sulfate was produced as the final products. Kelly et al. (1993) proposed that metabolism of COS by $T$. thioparus involves hydrolytic cleavage of COS to $\mathrm{CO}_{2}$ and $\mathrm{H}_{2} \mathrm{~S}$, and energy is generated from oxidation of $\mathrm{H}_{2} \mathrm{~S}$ to sulfate. Overmann and Gemerden (2000) also pointed out that the physiological metabolism of sulfide by Thiobacillus can produce sulfate. Chapman (1990) investigated autotrophic thiobacilli in 43 Scottish agricultural soils, neutrophilic thiobacilli, typically $T$. thioparus, were found in $84 \%$ of the soils with MPN (Most Probable Number) counts ranging from 1 to $10^{5} \mathrm{~g}^{-1}$. We also found the surface $\mathrm{HS}^{-}$species in our in situ DRIFTS experiment (Fig. 4A).

In addition, $\mathrm{H}_{2} \mathrm{~S}$ oxidation by $\mathrm{Fe}$ (III) might be another loss path for $\mathrm{H}_{2} \mathrm{~S}$. The iron oxides goethite, lepidocrocite, ferrihydrite and hematite are important $\mathrm{Fe}$ (III)-containing constituents in soils (Neal et al., 2001). Reductive dissolution of hematite by

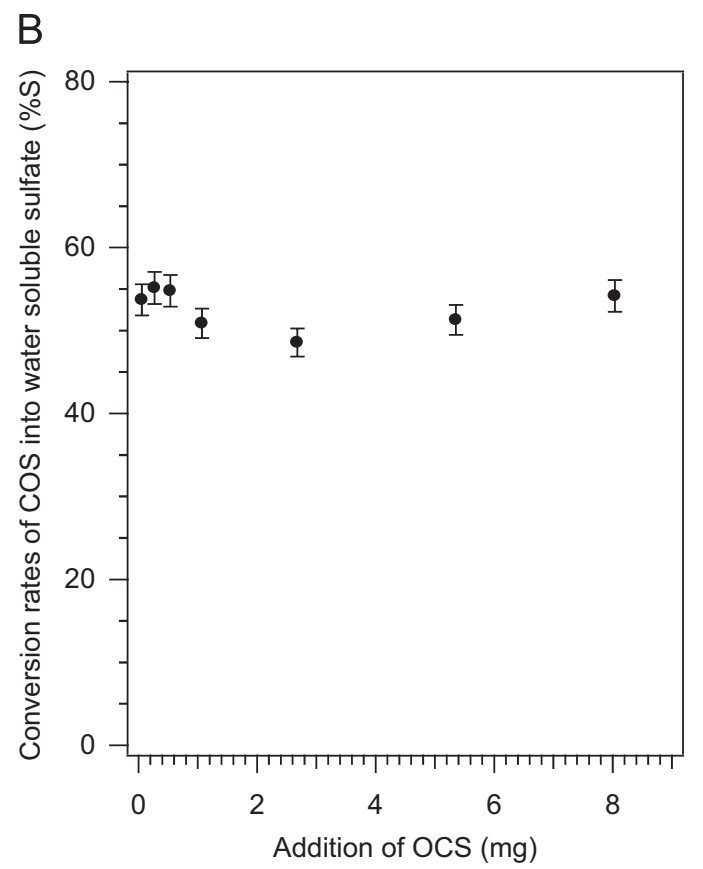

Fig. 5. (A) The conversion rates of water-soluble sulfate in relation to the exposure time in the original lawn soil at $298 \mathrm{~K}$. The initial addition of COS was $1.072 \mathrm{mg}$. (B) The conversion rates of water-soluble sulfate vary with COS addition (mg). All the data replicated two or three times and used the average value. 
$\mathrm{H}_{2} \mathrm{~S}$ is complex, and many intermediates $\left(\mathrm{S}_{n}^{2-}\right.$, $\mathrm{SO}_{3}^{2-}, \mathrm{SO}_{4}^{2-}$ and $\mathrm{S}_{2} \mathrm{O}_{3}^{2-}$ ) were observed (Pyzik and Sommer, 1981; dos Santos Afonso and Stumm, 1992; Davydov et al., 1998; Herszage and dos Santos Afonso, 2000; Neal et al., 2001). dos Santos Afonso and Stumm postulated the formation of $\mathrm{FeS}^{-}$and $\mathrm{FeSH}$ surface complexes by exchange $\mathrm{O}^{2-}$ for $\mathrm{S}^{2-}$ and $\mathrm{HS}^{-}$, these new surface groups would then undergo electron transfer (dos Santos Afonso and Stumm, 1992). The existence of $\mathrm{SH}^{-}$and $\mathrm{SO}_{3}^{2-}$ groups at the hematite surface has been confirmed using FTIR spectroscopy (Neal et al., 2001), and it was also observed on the soil surface after being exposed to COS by this study.

Therefore, we proposed that the lawn soil uptake COS may start with the enzymatic catalysis by CA enzyme or hydrolysis to form $\mathrm{CO}_{2}$ and $\mathrm{H}_{2} \mathrm{~S}$, and then $\mathrm{H}_{2} \mathrm{~S}$ is quickly converted into sulfate by Thiobacillus and Fe (III).

To certify whether $\mathrm{H}_{2} \mathrm{~S}$ is the intermediate of the conversion of COS, similar experiments were also performed for the uptake and conversion of $\mathrm{H}_{2} \mathrm{~S}$ in the lawn soil. Compared with $\mathrm{COS}$, the conversion rate of $\mathrm{H}_{2} \mathrm{~S}$ in the original lawn soil to sulfate was about same level as that of COS (Figs. 5A and 6B), although $\mathrm{H}_{2} \mathrm{~S}$ could be easier to be absorbed or reacted in the soils due to its high reactivity (Figs. 2 and 6A). Therefore, the conversion of $\mathrm{COS}$ to water-soluble sulfate might be through $\mathrm{H}_{2} \mathrm{~S}$ in the lawn soil.

The results of duplicated experiments $(n=3)$ of $8.04 \mathrm{mg}$ COS uptake by $50 \mathrm{~g}$ lawn soil (water
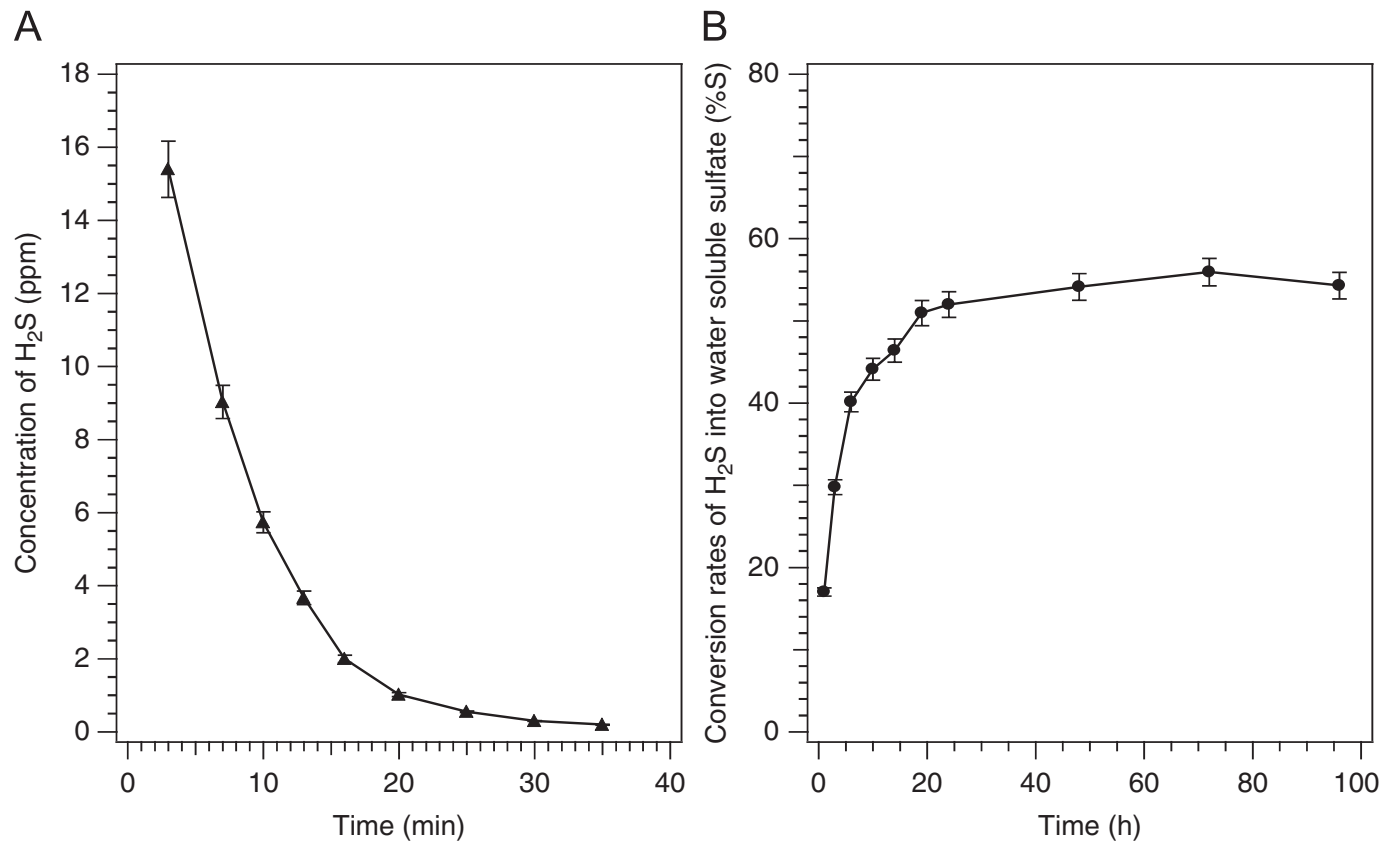

Fig. 6. (A) The concentration of $\mathrm{H}_{2} \mathrm{~S}$ versus time in the lawn original soil sample at $298 \mathrm{~K}$. (B) Conversion rates of water-soluble sulfate in relation to the exposure time in the lawn original soil sample at $298 \mathrm{~K}$. The initial addition of $\mathrm{H}_{2} \mathrm{~S}$ was $0.702 \mathrm{mg}$.

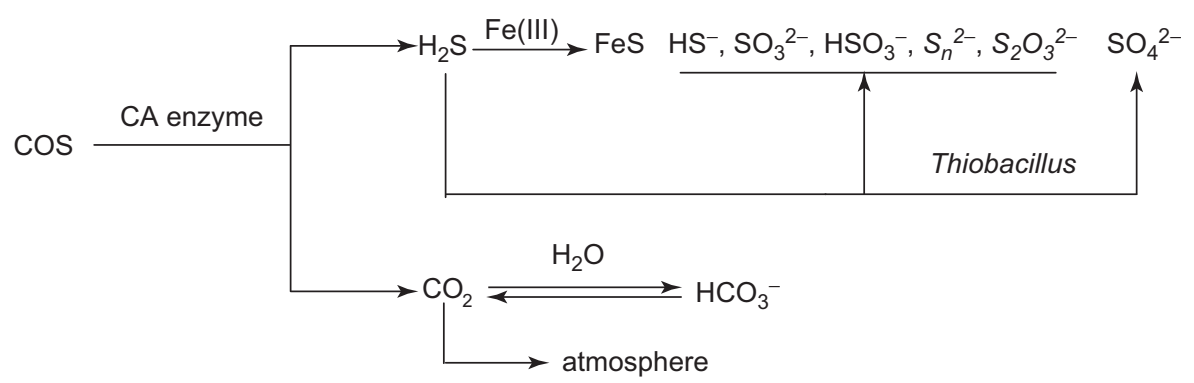

Fig. 7. Mechanism of conversion of COS in the lawn soil. 
content was $10.5 \%$ ) at $298 \mathrm{~K}$ showed that the total sulfur (Liu, 1996) in the lawn soil before and after the COS uptake was $195 \pm 2 \mathrm{mg} \mathrm{Kg}^{-1}$ and $289 \pm$ $8 \mathrm{mg} \mathrm{Kg}^{-1}$ (dry weight), respectively, indicating that the consumed COS by the lawn soil was completely converted to other sulfur compounds.

On the basis of above knowledge, we conclude that the uptake and conversion of COS in the lawn soil can be illustrated as the following possible schematic (Fig. 7). The COS consumed by the lawn soil mainly through the CA enzyme to produce $\mathrm{CO}_{2}$ and $\mathrm{H}_{2} \mathrm{~S}$, and then carbon dioxide reacts with water in the soil to forming hydrogen carbonate. $\mathrm{H}_{2} \mathrm{~S}$ is probably oxidized by $\mathrm{Fe}$ (III) or sulfur-oxidizing bacteria-Thiobacillus thioparus in the lawn soil, and produces water soluble sulfate and other sulfur compounds.

\section{Conclusions}

The uptake rates of COS by the lawn soil depended on ambient temperature, soil water content, soil type, and so on. The non-linear relationships between COS uptake rates and temperature as well as soil water contents indicated that COS consumption in the lawn soil was probably dominated by biological processes. About half of consumed COS by the lawn soil was converted into water-soluble sulfate through $\mathrm{H}_{2} \mathrm{~S}$. Because the water-soluble sulfate is the major available sulfur for plants, the uptake of COS by soils might be a path of sulfur supplement for vegetables especially in remote areas.

\section{Acknowledgments}

We acknowledge the fundamental support by the National Natural Science Function of China (20577064, 40275038) and 973 Project (2005CB422201).

\section{References}

Adams, D.F., Farwell, S.O., Robinson, E., Pack, M.R., Bamesberger, W.L., 1981. Biogenic sulfur source strengths. Environmental Science and Technology 15, 1493-1498.

Amenomiya, Y., Morikawa, Y., Pleizier, G., 1977. Infrared spectroscopy of $\mathrm{C}^{18} \mathrm{O}_{2}$ on alumina. Journal of Catalysis 46 , $431-433$.

Andreae, M.O., Crutzen, P.J., 1997. Atmospheric aerosols: biogeochemical sources and role in atmospheric chemistry. Science 276, 1052-1058.
Bartell, U., Hofmann, U., Hofmann, R., Kreuzburg, B., Andreae, M.O., Kesselmeier, J., 1993. COS and $\mathrm{H}_{2} \mathrm{~S}$ fluxes over a wet meadow in relation to photosynthetic activity: an analysis of measurements made on 6 September 1990. Atmospheric Environment 27A, 1851-1864.

Castro, M.S., Galloway, J.N., 1991. A comparison of sulfur-free and ambient air enclosure techniques for measuring the exchange of reduced sulfur gases between soils and the atmosphere. Journal of Geophysical Research 96, 15427-15437.

Chang, C.C., 1978. Infrared studies of $\mathrm{SO}_{2}$ on $\gamma$-alumina. Journal of Catalysis 53, 374-385.

Chapman, S.J., 1990. Thiobacillus populations in some agricultural soils. Soil Biology and Biochemistry 22, 479-482.

Conrad, R., Meuser, K., 2000. Soils contain more than one activity consuming carbonyl sulfide. Atmospheric Environment 34, 3635-3639.

Crutzen, P.J., 1976. The possible importance of CSO for the sulfate layer of the stratosphere. Geophysical Research Letters 3, 73-76.

Davydov, A., Chuang, K.T., Sanger, A.R., 1998. Mechanism of $\mathrm{H}_{2} \mathrm{~S}$ oxidation by ferric oxide and hydroxide surfaces. Journal of Physical Chemistry B 102, 4745-4752.

dos Santos Afonso, M., Stumm, W., 1992. Reductive dissolution of iron(III) (hydr)oxides by hydrogen sulfide. Langmuir 8, $1671-1675$.

Goodman, A.L., Li, P., Usher, C.R., Grassian, V.H., 2001. Heterogeneous uptake of sulfur dioxide on aluminum and magnesium oxide particles. Journal of Physical Chemistry A $105,6109-6120$.

Herszage, J., dos Santos Afonso, M., 2000. The autooxidation of hydrogen sulfide in the presence of hematite. Colloids and Surfaces A 168, 61-69.

Hoggan, P.E., Aboulayt, A., Pieplu, A., Nortier, P., Lavalley, J.C., 1994. Mechanism of COS hydrolysis on alumina. Journal of Catalysis 149, 300-306.

Kelly, D.P., Malin, G., Wood, A.P., 1993. Microbial transformations and biogeochemical cycling of one-carbon substrates containing sulfur. In: Murrell, J.C., Kelly, D.P. (Eds.), Microbial Growth on $\mathrm{C}_{1}$ compounds. Intercept, nitrogen or halogens, Andover, England, pp. 47-63.

Kesselmeier, J., Hubert, A., 2002. Exchange of reduced volatile sulfur compounds between leaf litter and the atmosphere. Atmospheric Environment 36, 4679-4686.

Kesselmeier, J., Teusch, N., Kuhn, U., 1999. Controlling variables for the uptake of atmospheric carbonyl sulfide by soil. Journal of Geophysical Research 104, 11577-11584.

Khalil, M.A.K, Rasmussen, R.A., 1984. Global sources, lifetimes and mass balances of carbonyl sulfide (COS) and carbon disulfide $\left(\mathrm{CS}_{2}\right)$ in the earth's atmosphere. Atmospheric Environment 18, 1805-1813.

Kim, S.J., Katayama, Y., 2000. Effect of growth conditions on thiocyanate degradation and emission of carbonyl sulfide by thiobacillus thioparus THI115. Water Research 34, 2887-2894

Kuhn, U., Kesselmeier, J., 2000. Environmental variables controlling the uptake of carbonyl sulfide by lichens. Journal of Geophysical Research 105, 26783-26792.

Kuhn, U., Ammann, C., Wolf, A., Meixner, F.X., Andreae, M.O., Kesselmeier, J., 1999. Carbonyl sulfide exchange on an ecosystem scale: soil represents a dominant sink for atmospheric COS. Atmospheric Environment 33, 995-1008. 
Laniecki, M., Ziólek, M., Karge, H.G., 1987. Effect of water on the formation of $\mathrm{HSO}_{3}^{-}$ions upon $\mathrm{SO}_{2}$ adsorption onto faujasite-type zeolites. Journal of Physical Chemistry 91, 4-6.

Laperdrix, E., Sahibed-dine, A., Costentin, G., Saur, O., Bensitel, M., Nédez, C., Mohamed Saad, A.B., Lavalley, J.C., 2000. Reduction of sulfate species by $\mathrm{H}_{2} \mathrm{~S}$ on different metal oxides and promoted aluminas. Applied Catalysis B 26, 71-80.

Lavalley, J.C., Travert, J., Chevreau, T., Lamotte, J., Saur, O., 1979. Infrared study of coadsorption of $\mathrm{H}_{2} \mathrm{~S}$ and $\mathrm{CO}_{2}$ on $\gamma$ alumina. Journal of the Chemical Society, Chemical Communications 4, 146-148.

Lehmann, S., Conrad, R., 1996. Characteristics of turnover of carbonyl sulfide in four different soils. Journal of Atmospheric Chemistry 23, 193-207.

Liu, G.S., 1996. Soil Physical and Chemical Analysis and Description of Soil Profiles. Standards Press of China, Beijing, pp. 196-197.

Meunier, F.C., Ross, J.R.H., 2000. Effect of ex situ treatments with $\mathrm{SO}_{2}$ on the activity of a low loading silver-alumina catalyst for the selective reduction of $\mathrm{NO}$ and $\mathrm{NO}_{2}$ by propene. Applied Catalysis B 24, 23-32.

Mitchell, M.B., Sheinker, V.N., White, M.G., 1996. Adsorption and reaction of sulfur dioxide on alumina and sodiumimpregnated alumina. Journal of Physical Chemistry 100, $7550-7557$.

Möller, D., 1984. On the global natural sulphur emission. Atmospheric Environment 18, 29-39.

Morterra, C., Zecchina, A., Coluccia, S., Chiorino, A., 1977. I.r. spectroscopic study of $\mathrm{CO}_{2}$ adsorption onto $\eta-\mathrm{Al}_{2} \mathrm{O}_{3}$. Journal of the Chemical Society, Faraday Transactions I 73, $1544-1560$.

Mu, Y.J., Wu, H., Zhang, X.S., Jiang, G.B., 2002. Impact of anthropogenic sources on carbonyl sulfide in Beijing city. Journal of Geophysical Research 107, 4769-4775.

Neal, A.L., Techkarnjanaruk, S., Dohnalkova, A., McCready, D., Peyton, B.M., Geesey, G.G., 2001. Iron sulfides and sulfur species produced at hematite surfaces in the presence of sulfate-reducing bacteria. Geochimica et Cosmochimca Acta $65,223-235$.

Overmann, J., Gemerden, H.V., 2000. Microbial interactions involving sulfur bacteria: implications for the ecology and evolution of bacterial communities. FEMS Microbiology Reviews 24, 591-599.

Protoschill-Krebs, G., Wilhelm, C., Kesselmeier, J., 1996. Consumption of carbonyl sulphide (COS) by higher plant carbonic anhydrase (CA). Atmospheric Environment 30, 3151-3156.

Pyzik, A.J., Sommer, S.E., 1981. Sedimentary iron monosulfides: kinetics and mechanism of formation. Geochimica et Cosmochimica Acta 45, 687-698.

Radmer, R.J., Kok, B., 1979. Rate-temperature curves as an unambiguous indicator of biological activity in soil. Applied and Environmental Microbiology 38, 224-228.

Rege, S.U., Yang, R.T., 2001. A novel FTIR method for studying mixed gas adsorption at low concentrations: $\mathrm{H}_{2} \mathrm{O}$ and $\mathrm{CO}_{2}$ on $\mathrm{NaX}$ zeolite and $\gamma$-alumina. Chemical Engineering Science 56, 3781-3796.

Ren, Y.L., 1999. Is carbonyl sulfide a precursor for carbon disulfide in vegetation and soil? Interconversion of carbonyl sulfide and carbon disulfide in fresh grain tissues in vitro. Journal of Agricultural Food Chemistry 47, 2141-2144.

Saur, O., Bensitel, M., Mohammed Saad, A.B., Lavalley, J.C., Tripp, C.P., Morrow, B.A., 1986. The structure and stability of sulfated alumina and titania. Journal of Catalysis 99, 104-110.

Travert, A., Manoilova, O.V., Tsyganenko, A.A., Maugé, F., Lavalley, J.C., 2002. Effect of hydrogen sulfide and methanethiol adsorption on acidic properties of metal oxides: an infrared study. Journal of Physical Chemistry B 106, $1350-1362$.

Turco, R.P., Whitten, R.C., Toon, O.B., Pollack, J.B., Hamill, P., 1980. OCS, stratospheric aerosols and climate. Nature 283, 283-286.

Watts, S.F., 2000. The mass budgets of carbonyl sulfide, dimethyl sulfide, carbon disulfide and hydrogen sulfide. Atmospheric Environment 34, 761-779. 